\title{
HEMOCORRECTORS BASED ON PERFLUOROCARBON GAS-TRANSPORT BLOOD-SUBSTITUTING EMULSIONS
}

Sergei I. Vorobyev ${ }^{1}$, Sergey B. Bolevich ${ }^{1}$, Sergey V. Votrin ${ }^{1}$, Aleksandra S. Orlova ${ }^{1}$, Alexey A. Novikov ${ }^{1}$, Stefani S. Bolevich $^{1}$, Dmitrii V. Gudanovich ${ }^{2}$, Elena M. Morozova ${ }^{1}$, Maria K. Kartashova ${ }^{1}$, Alexandr N. Khitrov ${ }^{1}$ and Koka H.Yavlieva ${ }^{1}$ ${ }^{1}$ I.M. Sechenov First Moscow State Medical University (Sechenov University), Moscow, Russian Federation, Moscow, Russia

${ }^{2}$ Research Institute of SP N.V. Sklifosovsky, Moscow

\section{HEMOKOREKTORI ZASNOVANI NA PERFLUOROKARBONSKIM GASNO-TRANSPORTNIM EMULZIJAMA KOJE SE DODAJU U KRV \\ Sergej I. Vorobiev ${ }^{1}$, Sergej B. Bolevič ${ }^{1}$, Sergej V. Votrin ${ }^{1}$, Aleksandra S. Orlova ${ }^{1}$, Aleksej A. Novikov ${ }^{1}$, Stefani S. Bolevič $^{1}$, Dmitrij V. Gudanovič² ${ }^{\text {, Elena M. Morozova }}{ }^{1}$, Maria K. Kartašova ${ }^{1}$, Aleksandar N. Kitrov ${ }^{1}$ i Koka H.Yavlieva ${ }^{1}$ \\ ${ }^{1}$ I.M. Sechenov Prvi moskovski državni medicinski univerzitet (Sechenov univerzitet), Moskva, Ruska federacija, Moskva, Rusija ${ }^{2}$ Istraživački institut SP N. V. Sklifosovsky, Moskva, Rusija}

\begin{abstract}
Hemocorrectors based on perfluorocarbon gas-transport blood-substituting emulsions are complex multiphase systems used in the biomedical field as multifunctional drugs, in particular, as gas-transport substitutes for a blood donor. The aim of this review was to discuss their physicochemical and medico-biological properties. A number of preparations from both Russian and foreign manufacturers based on chemically inert perfluorocarbon blood-substituting emulsions of a nano-size level as hemocorrectors with a gas transport function are shown. The analysis of the effect of perfluorocarbon emulsion on the blood gas transport in dicators showed that perfluorocarbon particles in the bloodstream will significantly improve the conditions of gas exchange in tissues. The most important issue is the concentration of perfluorocarbon blood-substituting emulsions. The perfluorocarbon emulsions can be considered as a means of correcting the gas transport properties of blood, increasing the reserve capacity of blood cells-red blood cells to deliver oxygen to the tissues. Taking into account all facts about perfluorocarbon hemocorrectors, it can be concluded that they can be used as universal nanocarriers for the transdermal delivery of oxygen and biologically active compounds in various fields of biomedicine and cosmetology.
\end{abstract}

Keywords: hemocorrectors, perfluorocarbon gas-transport blood-substituting emulsions, biological characteristic, medical characteristic.

\section{SAŽETAK}

Hemokorektori zasnovani na perfluorokarbonskim gasno transportnim emulzijama koje se dodaju u krv su složeni multifazni sistemi koji se koriste u biomedicinskoj oblasti kao multifunkcionalni lekovi, posebno kao gasno transportni supstituti za donore krvi. Cilj ovog rada je da razmotri njihove fizičko-hemijske i mediko-biološke osobine. Jedan broj preparata od ruskih i stranih proizvođača zasnovanih na hemijski inertnim perfluorokarbonskim emulzijama koje se dodaju u krv na nivou nano-veličine kao hemokorektori sa gasno transportnom funkcijom su prikazani. Analiza dejstva perfluorokarbonske emulzije na gasno transportne indikatore krvi je pokazala da će perfluorokarbonske čestice u krvotoku značajno poboljšati uslove razmene gasova u tkivima. Najvažnija stvar je koncentracija perfluorokarbonskih emulzija koje se dodaju u krv. Perfluorokarbonske emulzije se mogu smatrati sredstvom korigovanja gasno transportnih svojstava krvi, povećavajući kapacitet rezervi krvnih ćelijacrvenih krvnih zrnaca da dopremaju kiseonik do tkiva. Uzimajući u obzir sve činjenice o perfluorokarbonskim hemokorektorima, može se zaključiti, da se mogu koristiti kao uiverzalni nanonosači za transdermalno dopremanje kiseonika i biološko aktivna jedinjenja u različitim oblastima biomedicine i kozmetologije.

Ključne reči: hemokorektori, perfluorokarbonske gasno transportne emulzije koje se dodaju u krv, biološke karakteristike, medicinske karakteristike. 


\section{INTRODUCTION}

Hemocorrectors based on the perfluorocarbon gastransport blood-substituting emulsions are complex multiphase systems of colloid chemistry that are successfully used in the medical and biological field as multifunctional drugs, in particular, as gas-transport substitutes for the donor blood.

Perfluorocarbon gas transport hemocorrectors are widely used in the treatment of various forms of anemia and blood loss, intravascular hemolysis and anaerobic infections, carbon monoxide poisoning and gas exchange disorders in the lungs, where it is necessary to restore the function of $\mathrm{O}_{2}$ transport.

Indications for the clinical use of the perfluorocarbon blood-substituting emulsions such as Perftoran are broadly used for all types of shock; metabolic and gas exchange disorders; circulatory disorders in multiple injuries; anti-ischemic protection of organs; use for hemodilution, in the absence of the donor blood and red blood cell mass, etc.

The perfluorocarbon emulsions are a multicomponent heterogeneous substance in which many processes occur simultaneously: the thermal motion of particles, molecular diffusion, clumping, and settling. The perfluorocarbon emulsion is an unstable system in which the dispersion of the system changes both as a result of coalescence and coagulation, and according to the laws of Ostwald ripening period.

Researchers of many research centers are trying to create aggregative and sedimentation-resistant hemocorrectors, in terms of the colloid-chemical properties of perfluoroemulsions, while maintaining their high medical and biological effectiveness. Several attempts have been made to search for and synthesize the proper perfluoro compounds and their emulsifiers with help of whom it would be possible to accomplish this task.

In Russia, this problem was partially solved (1-4) in domestic drugs using a binary mixture of two organofluorine compounds: perfluorodecalin and perfluoromethylcyclohexylpiperidine, stabilized by a block copolymer of ethylene oxide and propylene to an average size of gas carrier particles ("artificial red blood cell") from 30 to 150 nanometers inthe artificial plasma with electrolytes, followed by sterilization by dynamic ultrafiltration (Table 1).

In Japan, as the author points out (5-7), the emulsification of a binary mixture of perfluorodecalin and perfluorotropylamine (PFD/PFTPA) was carried out with a mixture of phospholipids and pluronic F-68, which did not allow for full sterilization of the Japanese blood-substituting emulsion Fluosol-DA $20 \%$. Since the point of turbidity of pluronic f-68 is approximately at a temperature of $115^{\circ} \mathrm{C}$, above which its effectiveness as an emulsifier decreases sharply.

In the US, the question was solved $(6,7)$ by using also a known emulsifier of phospholipid of an egg protein, which improved the stability of the US blood-substituting emulsion of Oxygent binary mixture of perftoroktilbromid and perftordioctilbromid (PFOB/PFDB) during sterilization - autoclaving, but with a partial loss of medico-biological efficiency (e.g.: rheology, hemodynamic properties, etc.).

\section{THE QUESTION OF ADEQUATE CONCENTRATION AND OXYGEN CAPACITY}

The most important issue is the concentration of perfluorocarbon blood-substituting emulsions. The opinions of scientists are very contradictory.

So, all American perfluorocarbon emulsions of the second generation that are undergoing clinical trials, such as Oxigent, Oxyfluor, Oxycyte, are very concentrated emulsions. The American researchers seem to assume that a high concentration of the gas carrier - perfluorocarbon - can bring the artificial hemocorrector closer to the level of oxygen capacity of the donor blood ( 20 vol.\%). Thus, the American drug Oxygent has an oxygen capacity of 24 vol.\% (at $\mathrm{pO}_{2}=760 \mathrm{mmHg}$ ), but the efficiency of oxygen return (or dynamic oxygen capacity) in their emulsions, due to their high viscosity, is very low $(0,77 \mathrm{vol} . \%)$. It is likely that in the future, created highly concentrated hemocorrectors with an oxygen capacity similar to that of the donor blood will be unpromising and not safe due to frequent allergic reactions (Table 2).

Our calculations show that if a $20 \%$ perfluorocarbon emulsion injected into the body at a dose of $10 \mathrm{ml} / \mathrm{kg}$ dissolves only $0,5 \%$ of $\mathrm{O}_{2}$, and the remaining $\mathrm{O}_{2}$ is carried by red blood cells - 98,2\% and plasma - 1,3\%, then an increase in the concentration of perfluorocarbons in the emulsion even twice (up to $40 \%$ ) will lead to an increase in oxygen dissolution to only $1 \%$ (at the same dose), but the viscosity of the blood-substituting emulsion will significantly increase. Obviously, this is not effective, and a further increase in the concentration or dose of the emulsion will not lead to the desired effect (Table 3).

In our opinion, the most promising emulsion of the second generation is likely to be the low concentrated $(1-10 \%)$ proksanola-fluorocarbon emulsion submicron level (nanoemulsion) type of FTRORANs (FTORemulsion-III). At first glance, the ability to gas-dissolve the low-concentrated perfluorocarbon emulsions is not large enough. So, $1 \%$ emulsion of Ftoran-1 dissolves oxygen only in 2,6-2,7 vol.\% (at $\mathrm{pO}_{2}$ $=760 \mathrm{mmHg}$ ), but the gas exchange surface characteristic of $1 \mathrm{~L}$ emulsion will be about $600 \mathrm{~m}^{2}$, which is slightly less than the surface of $1 \mathrm{~L}$ of red blood cells $-700 \mathrm{~m}^{2}$. 
Table 1. Compositions and physico-chemical properties of perfluorocarbon blood-substituting preparations-gas-transport hemocorrectors

FTOROSAN - PERFTORAN - FTORemulsion-III,

created in the USSR-Russia in the period 1979-2009.

\begin{tabular}{|c|c|c|c|c|}
\hline & \multicolumn{2}{|c|}{$\begin{array}{c}\text { I drug } \\
\text { Beloyartsev F.F. and Co. }\end{array}$} & $\begin{array}{c}\text { II drug } \\
\text { Vorobyev S.I. }\end{array}$ & $\begin{array}{c}\text { III drug } \\
\text { Vorobyev S.I. }\end{array}$ \\
\hline \multirow{2}{*}{ Components } & $\begin{array}{c}\text { FTOROSAN } \\
1979-1983\end{array}$ & $\begin{array}{c}\text { FTOROSAN } \\
\text { PERFTORAN } \\
1983-1985\end{array}$ & $\begin{array}{c}\text { PERFTORAN } \\
1986-1997\end{array}$ & $\begin{array}{c}\text { FTOR } \\
\text { emulsion-III } \\
1999-2009\end{array}$ \\
\hline & \multicolumn{2}{|c|}{$\begin{array}{c}\text { Clinical trial during } \\
1983-1985\end{array}$} & $\begin{array}{c}\text { Approved for the } \\
\text { usage }\end{array}$ & $\begin{array}{l}\text { Runs the } \\
\text { registration }\end{array}$ \\
\hline \multicolumn{5}{|c|}{ Chemical components (g): } \\
\hline Perfluorodecalin & 15,2 & 15,2 & 13,0 & 13,0 \\
\hline $\begin{array}{l}\text { Perfluoromethylcyclogesi } \\
\text { lpiperidin }\end{array}$ & 7,6 & 7,6 & 6,5 & 6,5 \\
\hline $\begin{array}{l}\text { Proxanol } 168 \\
(\mathrm{Mw}-8000 \mathrm{D})\end{array}$ & 3,8 & 3,8 & - & - \\
\hline $\begin{array}{l}\text { Proxanol } 268 \\
(\mathrm{Mw}-13000 \mathrm{D})\end{array}$ & - & - & 4,0 & 4,0 \\
\hline Sodium cloride & 0,6 & 0,597 & 0,6 & 0,6 \\
\hline Kalium chloride & 0,04 & 0,387 & 0,039 & 0,039 \\
\hline Magnesium chloride & 0,02 & 0,02 & 0,019 & 0,019 \\
\hline Sodium hydrocarbonate & 0,15 & 0,15 & 0,065 & 0,065 \\
\hline Sodium bicarbonate & - & 0,014 & 0,02 & 0,02 \\
\hline Calcium chloride & 0,03 & 0,028 & - & - \\
\hline Glucose & 0,18 & 0,2 & 0,2 & 0,2 \\
\hline Albumin & 3,0 & 3,0 & - & - \\
\hline $\mathrm{H}_{2} \mathrm{O}(\mathrm{ml})$ & до 100 & до 100 & до 100 & до 100 \\
\hline \multicolumn{5}{|c|}{ Physical, chemical and biological features: } \\
\hline $\begin{array}{l}\text { Average partial size } \\
(\mathrm{mkm})\end{array}$ & $0,10-0,15$ & $0,10-0,15$ & $0,03-0,15$ & $0,03-0,10$ \\
\hline $\begin{array}{l}\text { Dispersion: particals } \\
>0,2 \text { мкм }\end{array}$ & + & + & + & - \\
\hline Sterilisation of the drug & - & - & - & + \\
\hline Viscosity (sP) & 3,5 & 3,0 & 2,5 & 2,5 \\
\hline $\begin{array}{l}\text { Number of side effects } \\
(\%)\end{array}$ & $\sim 30 \%$ & $\sim 30 \%$ & $\sim 15-20 \%$ & $\sim 6-7 \%$ \\
\hline
\end{tabular}


Table 2. Gas transport properties of the Russian and American

blood-substituting emulsions of the second generation $[3,4,5,6]$.

\begin{tabular}{|c|c|c|c|c|c|}
\hline \multirow{2}{*}{ Features } & \multirow{2}{*}{ Blood } & \multicolumn{2}{|c|}{ Emulsion II generation (Russia) $)^{3,4}$} & \multicolumn{2}{|c|}{$\begin{array}{c}\text { Emulsion II generation } \\
(\text { USA })^{5,6}\end{array}$} \\
\hline & & $\begin{array}{c}\text { FTOR- } \\
\text { emulsion-III } 20\end{array}$ & $\begin{array}{c}\text { FTOR- } \\
\text { emulsion-III } 10\end{array}$ & $\begin{array}{l}\text { Oxigent } \\
\text { AF0104 }\end{array}$ & Oxigent AF0143 \\
\hline $\begin{array}{l}\text { Concentration of perfluororganic } \\
\text { compounds }\end{array}$ & Hct- $45 \%$ & $20 \%$ & $10 \%$ & $90 \%$ & $90 \%$ \\
\hline $\begin{array}{l}\text { Concentration of } \mathrm{O}_{2} \text { (relatively in } \\
\mathrm{pO}_{2}=760 \mathrm{~mm} \mathrm{Hg} \text { ), volume } \%\end{array}$ & 20 & 7 & 4 & 24 & 24 \\
\hline Viscosity, cP & 5 & 2,5 & 1,7 & 31 & 55 \\
\hline $\begin{array}{l}\text { Dynamic oxygen capacity } \\
\left(\mathrm{O}_{2} / \text { viscosity }\right) \text {, volume } \%\end{array}$ & 4 & 2,8 & 2,35 & 0,77 & 0,43 \\
\hline
\end{tabular}

Table 3. Gas transfer and oxygen dissolution with intravenous administration of $20 \%$ perfluorocarbon emulsion type FTORemulsion-III at a dose of $10 \mathrm{ml} / \mathrm{kg}[3,4]$.

\begin{tabular}{||l|c|c|c|c||}
\hline \multicolumn{1}{|c|}{ Components } & $\begin{array}{c}\text { Dissolution of } \mathrm{O}_{2} \\
(\%)\end{array}$ & $\begin{array}{c}\text { Const of Crog's } \\
\text { diffusion for } \mathrm{O}_{2}\end{array}$ & $\begin{array}{c}\text { Time of oxygenation } \\
(\mathrm{msec})\end{array}$ & $\begin{array}{c}\text { Gas exchange surface } \\
\left(\mathrm{m}^{2}\right)\end{array}$ \\
\hline Erythrocytes & 98,2 & - & $200-250$ & 3500 \\
\hline Plasma & 1,29 & $5,3 \cdot 10^{-5}$ & - & - \\
\hline Emulsion of perfluorocarbon & $0,5 *$ & $4,4 \cdot 10^{-4 * *}$ & $14-26^{* * *}$ & $8400^{* * * *}$ \\
\hline
\end{tabular}

*) increased mass transfer of $\mathrm{O} 2$ due to additional physically dissolved

$\mathrm{O} 2$ with $1 / 3$ in perfluorocarbons;

**) increased $\mathrm{O} 2$ mass transfer due to accelerated diffusion in perfluorocarbons;

***) increased $\mathrm{O} 2$ mass transfer due to high oxygenation rate in perfluorocarbons;

$* * * *$ ) increased $\mathrm{O} 2$ mass transfer due to larger gas exchange in perfluorocarbons.

With a decrease in the oxygen capacity in the lowconcentration blood-substituting emulsions of the Ftoran-1 type, the total gas diffusion rate can be successfully compensated by increasing the gas exchange surface where gas diffusion occurs, i.e., the total diffusion rate can be maintained by increasing the dispersion of the perfluorocarbon phase itself. The higher the dispersion, the larger the surface of phase's division and, consequently, the larger the gas exchange area.

There are two quantitative characteristics of emulsions: the maximum volume of the emulsion (Vmax) and the maximum surface of the emulsion (Smax). The maximum volume of the emulsion (Vmax) is not an objective characteristic. A more objective value is the maximum surface of the emulsion (Smax), which is determined by the number of submicron particles and depends on the dispersion of the emulsion - this is the maximum gas exchange surface through which the gases are diffused. In other words, by dispersing and breaking up 1 gram of perfluorocarbons to the average nanoparticle sizes of $30-80 \mathrm{~nm}$, a huge phase division can be obtained, i.e., the gas exchange area of $60 \mathrm{~m} 2$. (for example, 1 pill of activated carbon has the surface area of $125 \mathrm{~m} 2$ ).
The analysis of the effect of perfluorocarbon emulsion on the blood gas transport indicators showed that perfluorocarbon particles in the bloodstream will significantly improve the conditions of gas exchange in tissues by the following indicators: increasing the arterial-venous difference in $\mathrm{O} 2$ tension; changes in the conditions of oxygenation and deoxygenation of red blood cells; increasing the flow of oxygen from the blood to the tissues (in proportion to the gas voltage gradient), due to the increased solubility of gases in the perfluoroorganic phase, creating an additional reservoir for gases in the plasma or a damper that creates an additional flow for oxygen while it is being consumed. The perfluorocarbon emulsions can be considered as a means of correcting the gas transport properties of blood, increasing the reserve capacity of blood cells-red blood cells to deliver oxygen to the tissues $(10,11)$.

All of the above-mentioned effects of perfluorocarbons can and should appear already in the presence of a relatively low concentration of perfluorocarbons in the bloodstream. It can be argued, the author continues (10), that low concentrations of perfluorocarbons in the blood (up to 3-4 vol. $\%$ or $1,5-2,0 \%$ ) can have a disaggregating effect on red 
blood cells, thereby improving the fluidity and delivery of gases by red blood cells.

\section{ADVERSE REACTIONS OF PERFLUOROCARBON EMULSIONS}

Other positive characteristics of the perfluorocarbon hemocorrectors - low-concentrated proxanol-fluorocarbon nano-emulsions of the second generation are also certain. However, with all the positive properties of perfluorocarbon emulsions of the first and second generation, both proxanol and phospholipid, it is impossible not to point out their reaction, associated with both the activation of the blood plasma complement system and the activation of the macrophage activity on the introduction of actual particles of the perfluoro-emulsion. The adverse reactions have been shown to be mainly associated with large particles of the emulsion, both on proxanol and phospholipids, and with the toxicity of the emulsifier-pluronic F-68. These reactions are similar to the flu-like symptoms - pain in the sacrum, redness of the face, fever, sometimes manifestations of the anaphylactoid reactions. Similar manifestations are observed in the lipid emulsions for parenteral nutrition (without the perfluoro compounds). They are typical for many preparations containing particle dispersion with the adsorptive surface $(3,4)$.

However, as shown by our early studies (3), the number of reactions and their degree in the perfluorocarbon emulsions are different. Thus, the reactogenicity of the FTORemulsion-III emulsion (formerly called Perftoranplus) is $\sim 6,6 \%$, Perftoran $\sim 15-20 \%$, the Fluosol-DA emulsion $20 \%$ is apparently even higher than $\sim 30 \%$. The Oxygent emulsion also has side effects comparable in quantity to Fluosol-DA $20 \%$.

Our studies $(3,8)$ on the complement-activating effect of the American drug did not reveal the activation of the complement system by the Oxigent emulsion (AF0104), which underlines correctness of the assumption that the side reactions of phospholipid-fluorocarbon emulsions are associated with another system - reticulo-endothelial, with the activation of the macrophage activity. At the same time, the level of activation of the complement system of the Oxygent emulsion (AF0104), determined by the value of the neutropenic index in blood plasma, did not exceed the control values.

It should be noted that the domestic emulsifier proxanol268 , the analogue of which is pluronic F-68, activated the complement system in foreign researchers, in our experiments, it did not cause a similar reaction. This seems to be due to the physical and chemical structure of the foreign emulsifier and as our early experiments $(3,8)$ showed, to its toxicity.

It is known that the molecular weight of pluronic F-68 was $8300 \mathrm{D}$, its main hydrophobic block $21 \%$, while the toxicity of this emulsifier, studied in mice (LD50), was high and amounted to $9.4 \mathrm{~g} / \mathrm{kg}$. On the contrary, the domestic proxanol 268, which was used in our emulsions, was less toxic. This emulsifier had the molecular weight of $7200 \mathrm{D}$ and its main hydrophobic block-popr was $-19 \%$, the toxicity in LD50 mice was 2 times lower than the foreign analogue, and it was $20 \mathrm{~g} / \mathrm{kg}$. It is the possible activation of the complement system by pluronic F-68 that led many researchers to change the synthetic emulsifier to the animal phospholipid one. However, as clinical studies have shown, this did not completely solve the problem. Phospholipids, according to the American researchers, do not activate the complement system of blood plasma, but the phospholipidfluorocarbon emulsions, nevertheless, have reactogenicity. And this reactogenicity, as already noted, in our opinion, is associated with another reticuloendothelial system with phagocytosis (3-5).

All these factors were carefully taken into the account when creating new domestic blood-substituting emulsions of the FTORANs series. Therefore, there was no replacement of proxanol with phospholipids, given that the phospholipidfluorocarbon emulsions also showed negative characteristics.

The problem was that, after determining the system responsible for the occurrence of adverse reactions on the proxanol-fluorocarbon emulsions, and this, as already mentioned above, is the blood plasma complement system, it was necessary to eliminate or minimize the reasons for turning on the complement system. It turned out that the factor triggering the complement-activating effect of the emulsion is the dispersed composition of the emulsion particles, i.e. the reactogenicity of the drug increases as the total and average particle diameter increases, as well as the number of coarse particles in the emulsion.

\section{SORPTION ACTIVITY AND REACTOGENICITYOF PERFLUOROCARBON EMULSIONS}

Our study has shown (12) that from 20 to $35 \%$ of immunoglobulin $\mathrm{G}(\operatorname{IgG})$ are sorbed on the surface of the emulsion, and the dispersion of the obtained perfluoroemulsion particles plays an important role in this process. Thus, the coarse-gained emulsion with an average particle size of 0.5 microns sorbs up to $35 \% \mathrm{IgG}$ on its surface, while the microfine emulsion with a diameter of $50 \mathrm{~nm}(0,05$ microns) sorbs about $20 \%$ IgG. It is the sorption of IgG, as the most "reactogenic" immunoglobulin, that causes an increased activation of the blood plasma complement system. So, apparently, the sorption of a large amount of IgG on the surface of the perfluoro coarsed emulsion, compared with the fine emulsion, may be associated with less stable surface active layer consisting of a block copolymer of ethylene oxide and propylene, on the particles of the coarse emulsion. Since the sorption of IgG occurs, apparently, on the surface of the hydrophobic part of the perfluorocarbon drops, the $\operatorname{IgG}$ molecule will be able to shift the proxanol (emulsifier) molecule in a less strong and rather "loose" surface-active layer of the emulsifier of a coarse perfluoroalsifier. The 
surface-active layer of proxanol in the finely dispersed perfluoroacid emulsion is denser and more uniform; the surface of perfluorocarbons themselves is completely covered by a mono- or bilayer of proxanol. Therefore, the sorption activity of a fine emulsion concerning IgG sorption is less expressed.

To reduce the reactogenicity, it was supposed to create a strong, stable surface-active layer (surface-mechanical barrier) on the surface of the emulsion particles. The stable surface-active layer on the particles can be obtained under certain homogenization regimes, when the submicron-sized particles are created in the mass (about 99\%). In this case, the coarse particles with a "loose" less strong surface-active layer are further eliminated by dynamic ultrafiltration. This significantly reduces the most "attractive" sorption surface for "reactogenic proteins" of various molecular weights, mainly responsible for the complement.

As our further research (4) showed, this led to positive results. The reactogenicity of the blood-substituting emulsions of the FTORemulsion III type with a strong surfactant layer in clinical trials did not exceed $7 \%$.

The nano-dispersion emulsions, in the process of long and effective homogenization, have been shown to acquire aggregate stability of the dispersed phase due to the dense proxanol layer on the surface of the oil drop in the perfluoro compound, which consists of tightly intertwined hydrophilic chains - a structural and mechanical barrier-proxanol, which has certain structural and rheological properties. The use of modern high-tech technologies that provide the production of monodisperse nanoparticles with a narrow dispersion distribution a dense and homogeneous surface-active layer of proxanol, are factors that largely determine the properties of perfluoroemulsions. In addition, the active cleaning of emulsifiers and perfluorocarbons and sterilization of the perfluoroacid emulsion by dynamic ultrafiltration allow to improve the functional activity and significantly reduce the reactogenicity of perfluorocarbon gas-transport hemocorrectors.

\section{CONCLUSION}

In conclusion, it is necessary to note the main medical and biological characteristics of the gas-transport hemocorrectors -perfluorocarbon blood-substitutingemulsions: gas-transport, sorption, membrane stabilization, detoxification, anti-ischemic, cardioprotective, ophthalmoprotective, immunotropic, antioxidant, diuretic, anti-toxic, radio-and-chemoprotective, anti-burn, wound healing, nanoscale,etc. However, perfluorocarbon hemocorrectors can be used as universal nanocarriers for the transdermal delivery of oxygen and biologically active compounds in various fields of biomedicine and cosmetology.

\section{ACKNOWLEDGMENTS}

No funding was received from any sources.

\section{CONFLICT OF INTEREST}

Authors declare no conflict of interest.

\section{REFERENCES}

1. Beloyartsev FF. Perfluorinated carbons in biology and medicine. Perfluorinated carbons in biology and medicine. Sat. - Pushchino. 1980;5-21.

2. Vorobyev SI. Perftoran-plasma substitute with gas transport function. Preprint. Moscow. 1997: 1-48.

3. Vorobyev SI. Perfluorocarbon blood-substituting emulsions of the first and second generation. Chemical and pharmaceutical journal. 2009; 4(43):30-40.

4. Vorobyev SI, Moiseenko OM, Belyaev BL. et al. Colloid-chemical and medico-biological properties of the perfluorocarbon preparation "Fluoroemulsion III". Chemical and pharmaceutical journal. 2009;5(43): 37-43.

5. Riess JG. Fluorocarbon-based blood substitutes: what progress? Int J Artif Organs. 1991;14(5):255-8.

6. Riess JG. Fluorocarbon-based in vivo oxygen transport and delivery systems. Vox Sang. 1991;61(4):225-39.

7. Riess J, Flaim S, Rlein D, Weers J. The relative physiocochemical and biological attributes of perflubrom emulsion. Physiological activity of fluorinated compounds. SB. Pushchino. 1995:73-90.

8. Knunyants IL, Makarov KN, Snegirev VF. et al. Perfto$\mathrm{N}-$ (4-methylcyclohexyl) - piperidine as the basis of gascarrying perfusion media. Author's certificate. - No. 1094287. - 1984.

9. Makarov KN, Mirzabekyants NS, Snegirev VF. et al. Synthesis and physicochemical properties of perfluoroalkyl - and 1,4 dialkyl-substituted cyclohexanes. Perfluorinated carbons in biology and medicine. Sat. - Pushchino. 1980:21-30.

10. Kuznetsova IN, Gokhman NSh. solubility of oxygen and carbon dioxide in some organofluorine liquids and emulsions based on them. Problems of Hematology and blood transfusion. 1981; 26(6):51-54.

11. Kuznetsova IN, Herbut KA, Lyagushkin LV. The change in the mass transfer of gases of the blood under conditions of hypoxia during the infusion of an emulsion of perfluorocarbons. Physiological journal. 1986; 2(LXXII):231-238.

12. Vorobyev SI. Colloid-chemical characteristics of perfluorocarbon emulsions. Chemical and pharmaceutical journal. 2007; 11(41):67-72.

13. Sklifas AN, Shekhtman DG, Evdokimov VA, et al. Sorption of plasma components on the surface of particles of fluorocarbon emulsions stabilized by proxanol 268. Biofizika. 2002;47(5):926-32. 